\title{
Kepuasan Pengguna Media Aplikasi Interaktif Berbasis E-Learning Di Universitas Majalengka
}

\author{
Ii Sopiandi
}

\begin{abstract}
Abstrak-Keberhasilan sebuah Perguruan Tinggi di Fakultas Teknik salah satunya ditentukan oleh fasilitas dan kualitas media pembelajaran baik secara Hardwere ataupun Softwere dan Dosennya yang bermutu. Melihat perilaku mahasiswa dizaman modern sekarang tidak dipungkiri diperlukan Terobosan baru dalam segi pembelajaran. Media aplikasi Interaktif E-Lerarning untuk Skala Universitas ini hadir untuk menjembatani itu semua, antara Dosen dengan mahasiswa, yang diharapkan agar mahasiswa bisa lebih terbantu dan lebih efektif dalam pembelajaran karena setiap mahasiswa bisa mengakses materi dan tugasnya jika mahasiswa terjadi halangaan diakibatkan sakit atau keperluan jadi tidak tertinggal dari teman-temannya. Model pengembangan Sistem pada penelitian ini menggunakan pengembangan sistem Extreme Programming (XP) salah satunya mengembangkan perangkat lunak lebih sederhana dan bisa diterima oleh pengguna yang lain. Penelitian ini terbagi menjadi dua tahap. Tahap pertama meliputi Pengembangan dan Implementasi e-learning dan tahap kedua meliputi pengukuran, evaluasi berupa pembuatan model dan instrumen pengukuran. Adapun model dan instrumen pengukuran pada penelitian ini didasarkan pada model Customer Information Satisfaction (CIS), di mana setelah dilakukan pemilihan dan pengujian diperoleh 5 dimensi pengukuran yaitu customer service, security, ease of use, information content, dan innovation. Selanjutnya, berdasarkan 5 dimensi ini disusun instrumen pengukuran yang terdiri dari 14 butir ditambah satu butir yang mengukur kepuasan pengguna secara keseluruhan. Sedangkan survey dilakukan dengan menyebarkan kuesioner ke semua program studi secara proposional tergantung jumlah mahasiswa aktif tahun akademik berjalan.
\end{abstract}

Kata kunci: E-Lerarning; Extreme Programming (XP); Customer Information Satisfaction (CIS)

\section{Pendahuluan}

$\mathrm{P}$ Pada zaman dunia Pendidikan semakin maju dibutuhkan sebuah Era komputerisasi dalam pendidikan yang memfasilitasi mahasiswa dalam hal segi pembelajaran karena melalui media komputer sebagai salah satu kebutuhan mahasiswa dalam melakukan berbagai kegiatan pembelajaran akan terpenuhi dengan baik. Penyampaikan materi yang biasanya menggunakan metode ceramah dirasakan

Ii Sopiandi adalah pengajar di Program Studi Teknik Informatika, Fakultas Teknik, Universitas Majalengka email supiandi999@gmail.com masih kurang efektif, karena mahasiswa sering kali merasa jenuh sehingga materi yang disampaikan Dosen tidak dengan mudah dimengerti dan diterima oleh mahasiswa. Materi pembelajaran yang biasanya hanya melalui media cetak juga dirasakan kurang efektif, karena saat ini sudah banyak lembaga, institusi dan setiap individu manusia yang menggunakan media Teknologi Informasi dan Komunikasi. Penggunaan Teknologi Informasi dan Komunikasi, dipercaya dapat meningkatkan mutu dan kualitas dari pendidikan, serta dapat membantu proses pembelajaran mahasiswa. Salah satu upaya untuk meningkatkan mutu pendidikan yaitu dengan memanfaatkan teknologi informasi dan komunikasi dalam penyampaian materi pembelajaran. Di Universitas Majalengka, belum memiliki fasilitas media online sepereti E-learning, yang salah satu mamfaatnya adalah sebagai wadah untuk menyimpan materi yang diajarkan Dosen, sehingga mahasiswa tidak harus meminta langsung materi mata kuliah kepada Dosen yang bersangkutan akan tetapi bisa langsung download file nya di e-learning. Dengan melihat latar belakang di atas, penelitian memberikan judul "Kepuasan pengguna media aplikasi interaktif berbasis e-learning di Universitas Majalengka" Case studi di Universitas Majalengka, dengan penelitan ini diharapkan akan dapat membantu proses pembelajaran.

Berdasarkan latar belakang yang telah diuraikan di atas, maka penulis dapat mengidentifikasi masalah yang ditemukan yaitu sistem pembelajaran dengan metode pembelajaran yang lama seperti metode ceramah pada mahasiswa, dan tidak ditemukan adanya media aplikasi e-learning yang memfasilitasi mahasiswa dalam proses pembelajaran seperti dapat mendownload materi dimanapun dan kapanpun jika media e-learning tersedia. Berdasarkan identifikasi masalah yang telah diuraikan, maka penulis mengambil rumusan masalah sBagaimana merancang dan membangun Media aplikasi e-learning yang mudah dan digunakan untuk membantu proses pembelajaran bagi dosen dan mahasiswa dan Bagaimana menerapkan Media aplikasi e-learning ini bagi dosen dan mahasiswa dalam proses belajar mengajar di Universitas Majalengka.

Adapun Batasan masalah dari aplikasi e-learning ini adalah pengelolaan materi pembelajaran yang berbasis e-learning ini dibatasi pada materi yang berupa teks seperti file word, file PDF, zip dan powerpoint untuk video masih terkendala oleh system seperti 
membutuhkan upgrade system yang sangat besar, hardisk server yang besar untuk menampung berbagai jenis format video zaman sekarang dan E-lerning ini pengukuranya hanya di khususkan untuk mahasiswa baru.

\section{TINJAUAN PUSTAKA}

\section{Media Pendidikan}

Media bisa diartikan sebuah alat, sarana, perantara, dan penghubung untuk menyebar, membawa atau menyampaikan sesuatu pesan dan gagasan, sehingga dapat merangsang pikiran, perasaan, perbuatan, minat serta perhatian mahasiswa sedemikian rupa sehingga proses belajar mengajar terjadi pada diri mahasiswa. Dalam media pembelajaran terdapat dua unsur yang terkandung yaitu pesan atau bahan pengajaran yang akan disampaikan atau perangkat lunak dan alat penampil atau perangkat keras.

\section{Manfaat Media pada Pendidikan}

Adapun manfaat media pada pendidikan dalam proses belajar mengajar yaitu :

1. Memperjelas penyajian pesan agar tidak terlalu bersifat verbalistis (dalam bentuk katakata tertulis atau lisan saja).

2. Mengatasi keterbatasan ruang, waktu, dan daya indra, seperti objek yang terlalu besar objek yang terlalu besar dapat digantikan dengan realita gambaratau model.

3. Objek yang kecil objek yang terlalu kecil dapat dibantu dengan proyektor mikro atau gambar.

4. Gerak yang terlalu lambat atau terlalu cepat gerak yang terlalu lambat atau cepat dapat dibantu dengan timelapse /highspeed photography

\section{Aplikasi Interaktif}

Istilah aplikasi berasal dari bahasa inggris "application" yang berarti penerapan, lamaran ataupun penggunaan. Sedangkan secara istilah, pengertian aplikasi adalah suatu program yang siap untuk digunakan yang dibuat untuk melaksanakan suatu funsi bagi pengguna jasa aplikasi serta penggunaan aplikasi lain yang dapat digunakan oleh suatu sasaran yang akan dituju.

\section{Pengertian E-Learning}

Soekarwati [1] mendefinisikan e-learning sebagai berikut : "E-learning is a generic term for all technologically supported learning using a array of teaching and learning tools as phone bridging, audio and videotapes, teleconferencing, satellite transmissions, and the more recognized web-based training or computer aided". sumber belajar (learning resources) adalah semua sumber baik berupa data, orang dan wujud tertentu yang dapat digunakan oleh siswa dalam belajar, baik secara terpisah maupun secara terkombinasi sehingga mempermudah siswa dalam mencapai tujuan belajar atau mencapai kompetensi tertentu. Sumber belajar adalah bahan-bahan yang dimanfaatkan dan diperlukan dalam proses pembelajaran, yang dapat berupa buku teks, media cetak, media elektronik, narasumber, lingkungan sekitar, dan sebagainya yang dapat meningkatkan kadar keaktifan dalam proses pembelajaran.

\section{Karakteristik E-Learning}

Menurut Rosenberg [2] karakteristik E-learning bersifat jaringan, yang membuatnya mampu memperbaiki secara cepat, menyimpan atau memunculkan kembali, endistribusikan, dan sharing pembelajaran dan informasi. Karakteristik E-learning menurut Nursalam [3] adalah

1. Memanfaatkan jasa teknologi elektronik.

2. Memanfaatkan keunggulan komputer (digital media dan komputer networks)

3. Menggunakan bahan ajar yang bersifat mandiri (self learning materials) kemudian disimpan di komputer, sehingga dapat diakses oleh doesen dan mahasiswa kapan saja dan dimana saja.

Memanfaatkan jadwal pembelajaran, kurikulum, hasil kemajuan belajar, dan hal-hal yang berkaitan dengan administrasi pendidikan dapat dilihat setiap saat di komputer

\section{Manfaat E-Learning}

Manfaat E-learning adalah:

1. Fleksibel. E-learning memberi fleksibilitas dalam memilih waktu dan tempat untuk mengakses perjalanan.

2. Belajar Mandiri. E-learning memberi kesempatan bagi pembelajar secara mandiri memegang kendali atas keberhasilan belajar.

3. Efisiensi Biaya. E-learning memberi efisiensi biaya bagi administrasi penyelenggara, efisiensi penyediaan sarana dan fasilitas fisik untuk belajar dan efisiensi biaya bagi pembelajar adalah biaya transportasi dan akomodasi.

Manfaat E-learning menurut Pranoto [4] adalah:

1. Penggunaan E-learning untuk menunjang pelaksanaan proses belajar dapat meningkatkan daya serap mahasiswa atas materi yang diajarkan.

2. Meningkatkan partisipasi aktif dari mahasiswa.

3. Meningkatkan partisipasi aktif dari mahasiswa.dan Meningkatkan kemampuan belajar mandiri mahasiswa.

4. Meningkatkan kualitas materi pendidik dan pelatihan.

5. Meningkatkan kemampuan menampilkan informasi dengan perangkat teknologi informasi, dimana dengan perangkat biasa sulit dilakukan.

Kelebihan E-learning ialah memberikan fleksibilitas, interaktivitas, kecepatan, visualisasi melalui berbagai kelebihan dari masing-masing media, selain itu Elearning memiliki banyak kelebihan yaitu :

1. Lebih mudah diserap, artinya menggunakan fasilitas multimedia berupa gambar, teks, animasi, suara, video.

2. Jauh lebih efektif dalam biaya, artinya tidak perlu instruktur, tidak perlu minimum audiensi, bisa dimana saja, bisa kapan saja, murah untuk diperbanyak. 
3. Jauh lebih ringkas, artinya tidak banyak formalitas kelas, langsung pada pokok bahasan, mata pelajaran sesuai kebutuhan

\section{MEtode PENELITIAN}

\section{Model Pengembangan Sistem Extreme Programming (XP)}

Pada penelitian ini, digunakan Extreme Programming sebagai metode pengembangan software. Extreme Programming (XP) adalah disiplin pembangunan perangkat lunak berdasarkan nilai-nilai kesederhanaan, komunikasi, umpan balik, keberanian. Pada XP ini, setiap kontributor proyek adalah anggota "Whole Team", sebuah tim bisnis/pengembangan/pengujian tunggal yang menangani semua aspek pembangunan. Pusat pemikiran tim adalah "pelanggan", satu atau lebih bisnis yang bekerja sama dengan mereka setiap harinya. XP menggunakan bentuk sederhana dari perencanaan dan menganalisis untuk memutuskan apa yang harus dilakukan selanjutnya dan bersifat responsif bila ada fitur yang akan dikembangkan pada dimasa yang akan datang sebagai perkembangan keinginan pengguna. XP digunakan saat mengembangkan aplikasi yang berpusat pada pengguna dan digunakan oleh tim kecil. Siklus pengembangan software pada metode Extreme Programming (XP) mempunyai enam tahap (Gambar 1), yaitu sebagai berikut :

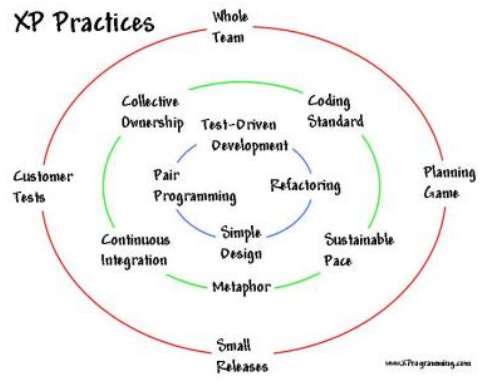

Gambar 1 Metode Extrim Progreming

\section{1) The Planning Game}

Pendekatan XP dalam perencanaan sangat mirip dengan metode yang diterapkan pada RAD (Rapid Application Development). Proses pendek dan cepat, mengutamakan aspek teknik, memisahkan unsur bisnis dengan unsur teknis dan pertemuan intensif antara klien dengan developer. Pada XP proses ini menggunakan terminologi "game" karena Beck menyarankan untuk menggunakan teknik score card dalam menentukan requirements. Semakin sulit aspek teknis yang dibutuhkan semakin tinggi pula skor pada kartu rencana tersebut

\section{2) Small Releases}

Setiap release dilakukan dalam lingkup sekecil mungkin pada XP. Setiap developer menyelesaikan sebuah unit atau bagian dari perangkat lunak maka hasil tersebut harus segera dipresentasikan dan didiskusikan dengan klien. Jika memungkinkan untuk menerapkan unit tersebut pada perusahaan, hal itu juga dapat dilakukan sekaligus sebagai tes awal dari penerapan keseluruhan sistem. Kendati demikian hal ini tidak selalu perlu dilakukan karena harus dihitung terlebih dahulu sumberdaya yang dibutuhkan. Apakah lebih menguntungkan langsung melakukan tes terhadap unit tersebut atau melakukan tes setelah unit tersebut terintegrasi secara sempurna pada sistem.

\section{3) Metaphor}

Metaphor pada dasarnya sama dengan arsitektur perangkat lunak. Keduanya menggambarkan visi yang luas terhadap tujuan dari pengembangan perangkat lunak. Beck sendiri seperti para penandatangan Agile Manifesto lainnya bercita-cita menyederhanakan proses pengembangan perangkat lunak yang saat ini sudah dianggap terlalu rumit. Arsitektur yang saat ini banyak berisi diagram dan kode semacam UML dianggap terlalu rumit untuk dimengerti, terutama oleh klien. Metaphor, walaupun mirip dengan arsitektur lebih bersifat naratif dan deskriptif. Dengan demikian diharapkan komunikasi antara klien dengan developer akan berlangsung lebih baik dan lancer dengan penggunaan metaphor

\section{4) Simple Design}

Sebagai salah seorang penandatangan Agile Manifesto, Beck adalah seorang yang tidak menyukai desain yang rumit dalam sebuah pengembangan perangkat lunak. Tidak heran jika dia memasukkan Simple Design sebagai salah satu unsur XP. Pada XP desain dibuat dalam lingkup kecil dan sederhana.Tidak perlu melakukan antisipasi terhadap berbagai perubahan di kemudian hari. Dengan desain yang simpel apabila terjadi perubahan maka membuat desain baru untuk mengatasi perubahan tersebut dapat dengan mudah dilakukan dan resiko kegagalan desain dapat diperkecil.

\section{5) Refactoring}

Refactoring adalah salah satu aspek paling khas dari XP. Refactoring seperti didefinisikan oleh Martin Fowler adalah "Melakukan perubahan pada kode program dari perangkat lunak dengan tujuan meningkatkan kualitas dari struktur program tersebut tanpa mengubah cara program tersebut bekerja". Refactoring sendiri sangat sesuai untuk menjadi bagian XP karena Refactoring mengusung konsep penyederhanaan dari proses desain maupun struktur baris kode program.Dengan Refactoring tim pengembang dapat melakukan berbagai usaha untuk meningkatkan kualitas program tanpa kembali mengulang-ulang proses desain. Fowler adalah salah satu kolega dekat dari Kent Beck karena itu tidak mengherankan bahwa cara berpikir mereka terhadap proses pengembangan perangkat lunak sangat mirip satu dengan lainnya.

\section{6) Testing}

XP menganut paradigma berbeda dalam hal test dengan model pengembangan perangkat lunak lainnya. Jika pada pengembangan perangkat lunak lainnya tes baru dikembangkan setelah perangkat lunak selesai menjalani proses coding maka pada XP tim pengembang harus membuat terlebih dahulu tes yang 
hendak dijalani oleh perangkat lunak. Berbagai model tes yang mengantisipasi penerapan perangkat lunak pada sistem dikembangkan terlebih dahulu. Saat proses coding selesai dilakukan maka perangkat lunak diuji dengan model tes yang telah dibuat tersebut. Pengetesan akan jauh lebih baik apabila dilakukan pada setiap unit perangkat lunak dalam lingkup sekecil mungkin daripada menunggu sampai seluruh perangkat lunak selesai dibuat. Dengan memahami tahap ini kita dapat melihat bahwa siklus pada XP adalah requirement analysis -> test -> code -> design. Sekilas terlihat hal ini tidak mungkin dilakukan tetapi pada kenyataannya memang gambaran inilah yang paling dapat menjelaskan tentang XP.

\section{7) Pair Programming}

Pair programming adalah melakukan proses menulis program dengan berpasangan. Dua orang programer saling bekerjasama di komputer yang sama untuk menyelesaikan sebuah unit. Dengan melakukan ini maka keduanya selalu dapat berdiskusi dan saling melakukan koreksi apabila ada kesalahan dalam penulisan program. Aspek ini mungkin akan sulit dijalankan oleh para programer yang memiliki ego tinggi dan sering tidak nyaman untuk berbagi computer bersama rekannnya.

\section{8) Collective Ownership}

Tidak ada satupun baris kode program yang hanya dipahami oleh satu orang programer. XP menuntut para programer untuk berbagi pengetahuan untuk tiap baris program bahkan beserta hak untuk mengubahnya. Dengan pemahaman yang sama terhadap keseluruhan program, ketergantungan pada programer tertentu ataupun berbagai hambatan akibat perbedaan gaya menulis program dapat diperkecil. Pada level yang lebih tinggi bahkan dimungkinkan para programer dapat bertukar unit yang dibangunnya.

\section{9) Coding Standards}

Pair programming dan collective ownership hanya akan dapat berjalan dengan baik apabila para programer memiliki pemahaman yang sama terhadap penulisan kode program. Dengan adanya coding standards yang telah disepakati terlebih dahulu maka pemahaman terhadap program akan menjadi mudah untuk semua programer dalam tim. Hal ini dapat diterapkan sebagai contoh pada penamaan variable dan penggunaan tipe data yang sama untuk tiap elemen semua record atau array pada program

\section{0) Continous Integration}

Melakukan build setiap hari kerja menjadi sebuah model yang disukai oleh berbagai tim pengembang perangkat lunak. Hal ini terutama didorong oleh keberhasilan penerapan sistem ini oleh Microsoft dan telah sering dipublikasikan. Dengan melakukan build sesering mungkin berbagai kesalahan pada program dapat dideteksi dan diperbaiki secepat mungkin. Apabila banyak tim pengembang perangkat lunak meyakini bahwa build sekali sehari adalah minimum maka pada XP hal tersebut adalah maksimum. Pada XP tim disarankan untuk melakukan build sesering mungkin misalnya setiap 4 jam atau bahkan lebih cepat lagi.

\section{1) 40-hours Week}

Beck berpendapat bekerja 8 jam sehari dan 5 hari seminggu adalah maksimal untuk tiap programer. Lebih dari itu programer akan cenderung membuat berbagai error pada baris-baris kode programnya karena kelelahan.

\section{2) On-Site Customer}

Sebuah pendekatan klasik, di mana XP menganjurkan bahwa ada anggota dari klien yang terlibat pada proses pengembangan perangkat lunak. Yang lebih penting lagi ia harus ada di tempat pemrogaman dan turut serta dalam proses build dan test yang dilakukan. Apabila ada kesalahan dalam pengembangan diharapkan klien dapat segera memberikan masukan untuk koreksinya

\section{Model Pengukuran CIS}

Model pengukuran kepuasan konsumen terhadap layanan penyediaan informasi melalui suatu sistem informasi telah cukup berkembang. Beberapa model yang dihasilkan di antaranya User 7 Information Satisfaction (UIS), End User Computing Satisfaction (EUCS), dan Customer Information Satisfaction (CIS) [5]. Instrumen UIS dibuat untuk mengukur kepuasan pengguna secara general terhadap informasi yang disediakan oleh unit pemrosesan data di suatu organisasi Sedangkan EUCS merupakan instrumen [6][7][8] yang meliputi 5 dimensi, yaitu konten, akurasi, format, kemudahan penggunaan, dan ketepatan waktu. EUCS adalah metode untuk mengukur tingkat kepuasan dari pengguna suatu sistem aplikasi dengan membandingkan antara harapan dan kenyataan dari sebuah sistem informasi. Model evaluasi EUCS ini dikembangkan oleh Doll \& Torkzadeh. Evaluasi dengan menggunakan model ini lebih menekankan kepada kepuasan (satisfaction) pengguna akhir terhadap aspek teknologi berdasarkan dimensi isi, keakuratan, format, ketepatan waktu dan kemudahan penggunaan sistem. UIS dan EUCS dianggap tidak cukup sesuai untuk penelitian ini karena keduanya terutama ditujukan untuk pemrosesan data konvensional atau pengguna akhir dari suatu sistem komputer [5]. Oleh karena itu dalam penelitian ini model yang akan digunakan sebagai dasar pengukuran adalah model CIS. model untuk mengevaluasi sistem informasi adalah End User Computing Satisfaction (EUCS).

Model dan instrumen penelitian didasarkan pada model Customer Information Satisfaction (CIS), di mana setelah dilakukan pemilihan dan pengujian diperoleh 5 dimensi pengukuran yaitu customer service, security, ease of use, information content, dan innovation. Selanjutnya, berdasarkan 5 dimensi ini disusun instrumen pengukuran yang terdiri dari 15 butir ditambah satu butir yang mengukur kepuasan pengguna 
secara keseluruhan. Sedangkan aplikasi survey yang dibuat merupakan bagian dari aplikasi network assistance yang merupakan aplikasi yang harus diakses oleh pengguna sebelum mereka bisa mengakses intranet dan internet di lingkungan Universitas Majalengka

\section{FlowMap}

Campuran peta dan flow chart, yang menunjukan pergerakan benda dari satu lokasi ke lokasi lain, seperti jumlah orang dalam migrasi, jumlah barang yang diperdagangkan, atau jumlah paket dalam jaringan. Flowmap menolong analisis dan programmer untuk memecahkan masalah ke dalam segmen-segmen yang lebih kecil dan menolong dalam menganalisis alternatifalternatif lain dalam pengoperasian.

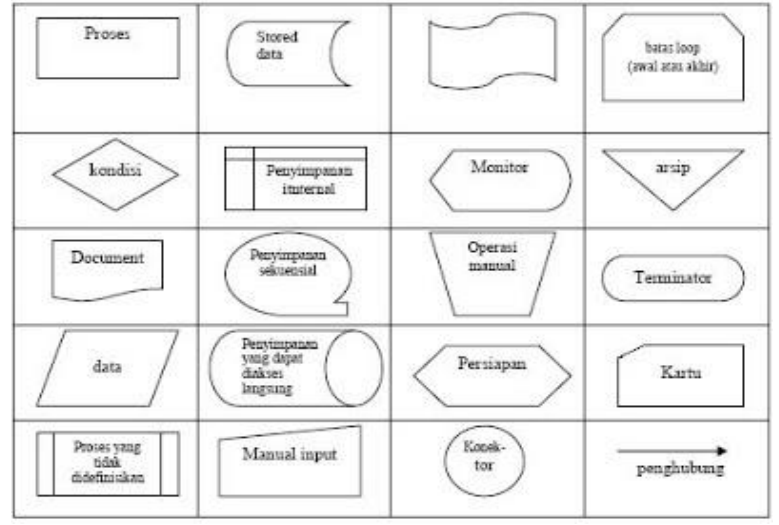

Gambar 2. Flow Map

\section{HASIL DAN PEMBAHASAN}

Proses pembelajaran / pemberian materi dari dosen kepada mahasiswa di fakultas teknik universitas majalengka dapat digambarkan dengan flowmap di Gambar 3.

Prosedur pemberian materi dari dosen kepada mahasiswa dapat diuraikan sebagai berikut :

1. Dosen membuat materi kuliah yang akan diajarkan kepada mahasiswa.

2. Dosen mengajarkan materi kepada mahasiswa.

3. Mahasiswa mencatat materi yang diajarkan dosen. Sehingga mahasiswa mempunyai catatan materi yang diajarkan dosen

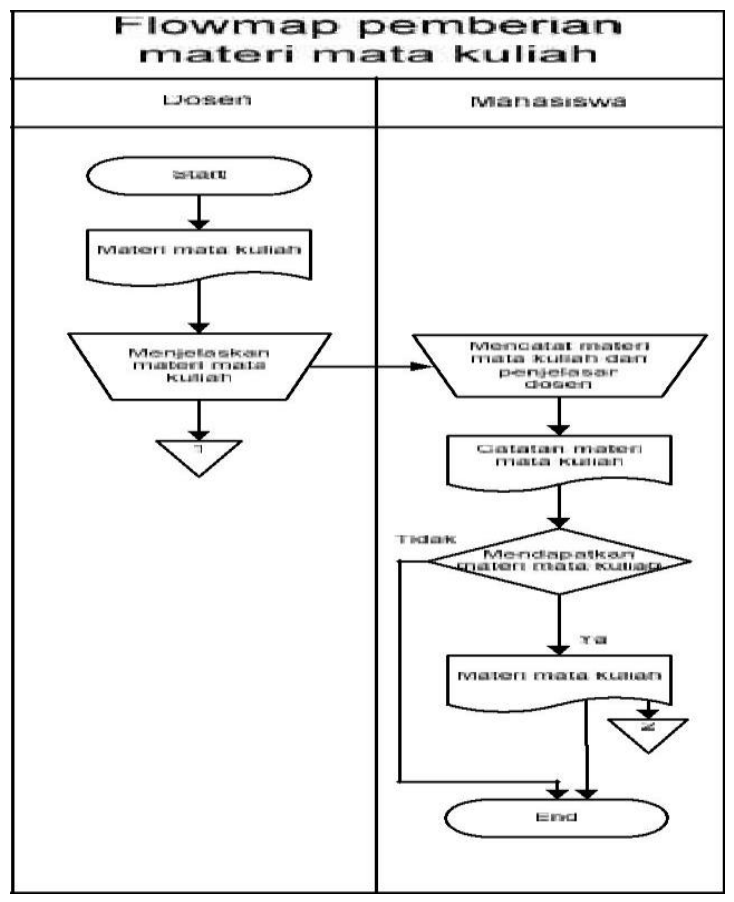

Gambar 3. Flow Map Proses Pemberian Materi Mata Kuliah

\section{Flowmap Usulan}

Pada flowmap ini adalah usulan yang akan memberikan gambaran E-learning terlihat pada Gambar 4.

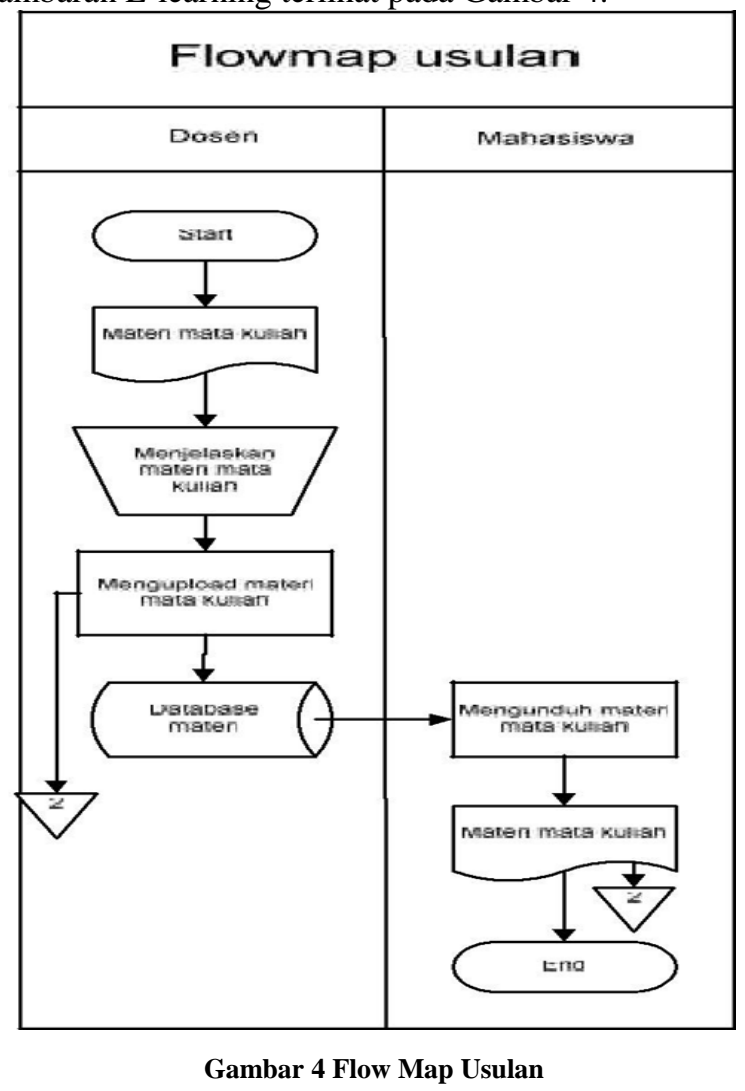

Pengukuran Kepuasan Pengguna Sistem Layanan Akademik dan Peningkatan Layanan Akademik Universtias Majalengka telihat pada Gambar 5. 


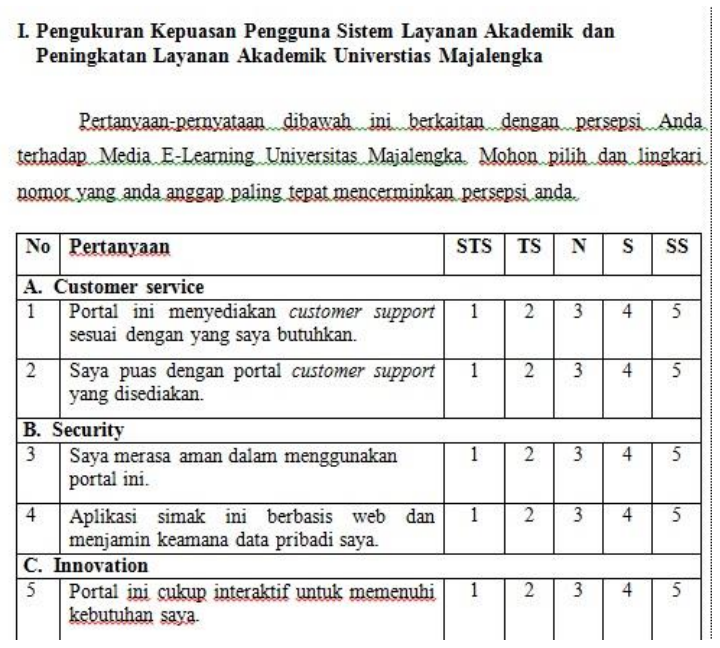

Gambar 5 Formulir Penilaian Sistem Layanan Akademik

\section{KESIMPULAN DAN SARAN}

Untuk mengukur kepuasan keseluruhan penulis tidak seluruh ditampilkan di journal ini, sebab akan panjang.hanya memberikan gambaran akan seperti apa. Penggunakaan metode ektrime programing $\mathrm{XP}$ untuk menganalisis pengembangan softwerenya sedangkan untuk mengukur kepuasanya menggunakan CIS

\section{DAFTAR PUSTAKA}

[1] Soekartawi, Prinsip Dasar e-Learning: Teori dan Aplikasinya di Indonesia, Jurnal Teknodik, Edisi Vol 7 No.12, 2003

[2] M.J. Rosenberg, E-Learning: Strategies for Delivering Knowledge in the Digital Age, NewYork: McGraw-Hill, 2001

[3] Nursalam, Pendidikan dalam Keperawatan, Jakarta: Salemba Medika, 2008

[4] A. Pranoto, Sains dan Teknologi, Jakarta: PT Gramedia Pustaka Utama, 2009

[5] Y.S. Wang, et all, An Instrument For Measuring Customer Satisfaction Toward Web Sites That Market Digital Products And Services, Journal of Electronic Commerce Research, VOL. 2, NO. 3, 2001

[6] F. Rangkuti, Measuring Customer Satisfaction: Teknik Mengukur dan Strategi Meningkatkan kepuasan Pelanggan. Jakarta:PT Gramedia Pustaka Utama, 2002

[7] D. Lestari, N.H.Waryanto,. Indikator User Satisfaction Dalam Layanan E-Learning. Jurusan Pendidkan Matematika FMIPA UNY. ISBN : 978 - $979-16353-9-4$.

[8] R. F. Gerson,. Mengukur Kepuasan Pelanggan. Cetakan kedua, Jakarta: PPM, 2002 